\title{
Endometriosis and Implantation
}

\author{
Endometriosis ve implantasyon \\ Gülnur KIZILAY ${ }^{1}$, Hakan ÇAKMAK², Aydın ARICI² \\ ${ }^{1}$ Department of Histology and Embryology, Medical Faculty of Trakya University, Edirne \\ ${ }^{2}$ Department of Obstetrics, Gynecology and Reproductive Sciences, Yale University School of Medicine, USA
}

Implantation is a complex process by which the embryo attaches to the endometrium. The human endometrium becomes receptive to the embryo during the luteal phase of the menstrual cycle under the influence of steroid hormones and paracrine factors originating from endometrial cells and the embryo. Several paracrine factors influencing the implantation include leukemia inhibitory factor (LIF) and interleukin (IL)-11. Moreover, timely development of pinopodes, and expression of integrins and Hox genes in endometrium, and oocyte quality also determines the implantation outcome. Endometriosis is a common gynecologic disorder and estimated that 25 to $50 \%$ of infertile women have endometriosis. Although the mechanisms contributing to infertility are poorly understood, accumulating evidence suggests that altered folliculogenesis, sperm dysfunction, impaired fertilization, toxicity against early embryonic development, defective implantation, and poor oocyte quality with decreased ability to implant may be the contributing factors in some endometriosis patients. Key Words: Implantation; endometriosis; infertility, oocyte quality.
Implantasyon, embriyonun endometriuma yerleşmesinin gerçekleştiği kompleks bir işlemdir. İnsan endometriumu; endometrial hücreler ve embriyodan kaynaklanan steroid hormonlar ve parakrin faktörlerin etkisi altında, luteal faz süresince embriyoyu kabul etmeye hazır hale gelir. Lösemi inhibitor faktör (LIF) ve interlökin (IL)-11'de dahil olmak üzere, pek çok parakrin faktör implantasyonu etkiler. Bunun yanısıra endometriyumda gelişen pinopodlar, integrinler, HOX genleri ve aynı zamanda oosit kalitesi de implantasyon sonucunu belirler. Endometriosis; yaygın bir jinekolojik hastalıktır ve infertil kadınların yaklaşık \%25-50'si endometriosislidir. Infertiliteye sebep olan mekanizmalar tam olarak anlaşılamamış olmasına rağmen, bu konu hakkındaki genel kanı; normal olmayan folikülogenez, sperm disfonksiyonu, implantasyon başarısızlığı, erken dönem embriyo gelişimine karşı oluşan toksisite, implante olma yeteneği azalmış düşük oosit kalitesinin bazı endometriosisli hastalarda infertiliteye neden olan etkili faktörler olabileceği yönündedir.

Anahtar Sözcükler: İmplantasyon; endometriosis; infertilite; oosit kalitesi.
Endometriosis is a common gynecologic disorder characterized by the presence of endometrial tissue outside the uterine cavity. Nearly more than a century has passed since the first description of endometriosis by Von Rokitansky in 1860 but our current understanding of the pathogenesis of the disease still remains unclear. ${ }^{[1]}$

Endometriosis is one of the leading causes of disability among reproductive age women and represents a major personal and public health

Trakya Univ Tip Fak Derg 2007;24(2):90-97

Correspondence (illetişim adresi): Dr. Aydın Arıcı. Section of Reproductive Endocrinology and Infertility, Department of Obstetrics, Gynecology and Reproductive Sciences, Yale University School of Medicine, 300 George Street, 7th Floor, New Haven, CT, 06510 USA.

Tel: 00-1-203-785-3581 Fax (Faks): 00-1-203-785-7134 e-mail (e-posta): aydin.arici@yale.edu

${ }^{\oplus}$ Trakya Üniversitesi Tıp Fakültesi Dergisi. Ekin Tıbbi Yayıncııık tarafından basılımışır. Her hakkı sakııdır.

${ }^{\circ}$ Medical Journal of Trakya University. Published by Ekin Medical Publishing. All rights reserved. 
concern. ${ }^{[2]}$ It affects 10 to $15 \%$ of women of reproductive age. It is estimated that 25 to $50 \%$ of infertile women have endometriosis, and among women with endometriosis 30 to $50 \%$ are infertile. ${ }^{[3,4]}$ Although the mechanisms contributing to infertility are poorly understood, accumulating evidence suggests that altered folliculogenesis, ${ }^{\left[{ }^{[}\right]}$ ovulatory dysfunction, ${ }^{[6]}$ sperm dysfunction, ${ }^{[7]}$ impaired fertilization, ${ }^{[8,9]}$ toxicity against early embryonic development, ${ }^{[10,11]}$ defective implantation $^{[12]}$ and poor oocyte quality with decreased ability to implant ${ }^{[13]}$ may be the contributing factors in some endometriosis patients.

\section{ENDOMETRIOSIS IS AN INFLAMMATORY DISEASE}

The peritoneal environment of women with endometriosis is pro-inflammatory and may play a prominent role in the establishment and progression of endometriosis. ${ }^{[14]}$ The peritoneal fluid of women with endometriosis contains increased numbers of immune cells, and macrophages are known to be the immune cell type found in the greatest quantity in the peritoneal fluid. ${ }^{[15]}$ Macrophages that would be expected to clear endometrial cells from the peritoneal cavity seem to allow endometriosis implants to persist and progress by secreting growth factors and cytokines. In women with endometriosis, the peritoneal fluid has high concentrations of proinflammatory cytokines, growth factors including interleukin (IL)- $1{ }^{[16-18]}$ IL- $8{ }^{[18-20]}$ monocyte chemotactic protein-1 (MCP-1), ${ }^{[21,22]}$ regulated upon activation, normal $\mathrm{T}$ cell expressed and secreted (RANTES), ${ }^{[23]}$ tumor necrosis factor- $\alpha$ $(\mathrm{TNF}-\alpha)^{[24]}$ and vascular endothelial growth factor (VEGF). ${ }^{[24]}$ Pelvic inflammation in endometriosis may lead to adhesion formation and scarring, disruption of fallopian tube patency, and anatomical distortion of the reproductive tract, which may affect the fertility. However, infertility is also associated with minimal or mild endometriosis and therefore, it requires the identification of other pathophysiological mechanisms.

\section{EFFECTS OF ENDOMETRIOSIS ON OOCYTE QUALITY}

Embryo competence is determined, at least in part, by the quality of the original gametes. The impaired quality of the embryos in endometriosis points to the follicular microenvironment and the quality of the oocyte that might be compromised. This suggests that infertility may be related to alterations within the follicle, which results in embryos of lower quality and capacity to implant. ${ }^{[25]}$ Multivariate analysis also shows a decrease in fertilization and implantation rates and a significant decrease in the number of oocytes retrieved for endometriosis patients. Stage of disease is also influential, because women with severe endometriosis displays significantly lower rates than women with mild disease. ${ }^{[25]}$

Autocrine and paracrine factors are able to modulate ovarian function apart from gonadotropins and ovarian steroids. These factors can be secreted by granulosa cells and ovarian leukocytes. In the follicular fluid of women with endometriosis, the level of VEGF is decreased, and the levels of IL-1, IL-6, IL-8, TNF- $\alpha$, MCP-1, growth regulated- $\alpha$ (Gro- $\alpha$ ) and endothelin-1 are elevated. ${ }^{[26-29]}$ Increased follicular fluid TNF- $\alpha$ level corresponds with poorquality oocytes. ${ }^{[30]}$ Moreover, decreased follicular fluid VEGF levels have been correlated with unhealthy follicular vascular network. ${ }^{[31]}$ Elevated IL-1 and TNF- $\alpha$ may also inhibit gonadotropin-induced progesterone production by granulosa cells as well as androgen production by theca cells. ${ }^{[2,33]}$ On the other hand, granulosa cell apoptosis, which may affect oocyte quality, has been shown to be increased in women with endometriosis. ${ }^{[34,35]}$ Patients with more advanced stages of endometriosis presents a higher apoptotic incidence in their granulosa cells, and significant differences are found in the number of oocytes and the fertilization rate. ${ }^{[36]}$ Furthermore, patients with endometriomas have even a higher incidence of apoptosis than women with endometriosis but without endometriomas. ${ }^{[37]}$

\section{EFFECT OF ENDOMETRIOSIS ON EARLY EMBRYONIC DEVELOPMENT}

A hostile peritoneal environment to the embryo has been postulated as a cause for the decreased 
fertility in endometriosis. Several studies reveal that peritoneal fluid from women with endometriosis impairs early embryo development. ${ }^{[38-40]}$ The peritoneal fluid from infertile women with endometriosis is embryotoxic to two-cell mouse embryos. However, this embryotoxicity is not prominent when peritoneal fluid is taken from fertile women with endometriosis. ${ }^{[41]}$ Moreover, increased aberrant nuclear and cytoplasmic events in embryos, decreased embryo cleavage rates, increased percentage of arrested development, and a significant decrease in the number of blastomeres has been demonstrated in women with endometriosis. ${ }^{[42-44]}$

\section{EFFECTS OF ENDOMETRIOSIS IN IMPLANTATION}

Implantation is a complex process by which the embryo attaches to the endometrium, first penetrating the endometrial epithelium and then invading the maternal circulatory system to form the placenta. ${ }^{[4]}$ Timely modifications in the endometrium to become receptive to the developing embryo are crucial for successful implantation. ${ }^{[4]}$ The human endometrium becomes receptive to the embryo only for a limited period during the luteal phase of the menstrual cycle, under the influence of steroid hormones and paracrine factors originating from endometrial cells and the embryo. ${ }^{[4]}$ The period during which endometrium is receptive to implantation, termed the implantation window, begins approximately six days after ovulation and is believed to encompass cycle days 20-24. ${ }^{[48]}$

Impaired endometrial receptivity is considered to be a major limiting factor for the establishment of pregnancy. ${ }^{[49]}$ In an attempt to develop a clinically relevant and reproducible evaluation of endometrial function, a number of molecular and morphological markers specific to the implantation window have been identified. These include pinopodes, integrins, leukemia inhibitory factor (LIF), the IL-1 system, glycodelin, colony stimulating factor-1 (CSF-1), heparin-binding epidermal growth factor (HB-EGF) and the Hox genes. ${ }^{[4,47,50,51]}$ Although these markers have been shown to be essential for implantation in animal models, fur- ther studies are needed to reveal their roles in human implantation. ${ }^{[77,48]}$

Pinopodes are cytoplasmic protrusions on the apical surface of the luminal epithelium. They can be visualized by scanning electron microscopy and the surfaces pinopodes may have some receptors for adhesion molecules, which are essential of embryo implantation. ${ }^{[52]}$ Human blastocysts are reported to attach preferentially to cultured endometrial epithelial cells expressing pinopodes rather than to areas of microvilli. Pinopodes are progesterone dependent structures whose appearance coincides with the onset of the receptive phase. ${ }^{[53]}$ They may therefore provide a measure of adequate endometrial maturation in response to progesterone. However, to date, there are no convincing data to show that pinopode expression in women correlates with implantation success. Nor is it clear whether pinopodes participate directly in the attachment of the embryo to the endometrium. In a prospective study evaluating pinopode formation in women with and without endometriosis, who undergo oocyte donation, demonstrates no difference between the two groups. ${ }^{[54]}$

Hox genes are transcriptional regulators that play an essential role in determining tissue identity during embryonic development. ${ }^{[5]}$ They are involved in the development of the Mullerian duct system and then continue to be expressed in the adult uterus. ${ }^{[50]}$ Hox genes are likely key regulators of human implantation. ${ }^{[5]}$ Hoxa-10 and Hoxa-11 genes are essential for implantation in the mouse and appear to play a similar role in human endometrium. ${ }^{[5]}$ However, eutopic endometrium of women with endometriosis fails to show the expected midluteal rise in Hox 10 and Hoxa-11 gene expression as demonstrated in the controls. ${ }^{[56]}$ Aberrant Hox gene expression suggests that altered development of the endometrium at the molecular level may contribute to the etiology of infertility in women with endometriosis.

Empty spiracles homolog 2 (EMX2) is also a transcriptional factor necessary for reproductive tract development and Hoxa-10, which is regulat- 
ed by sex steroids, negatively regulates EMX2 expression. ${ }^{[57]}$ Menstrual cycle dependent expression of EMX2 is demonstrated in eutopic endometrium of women with and without endometriosis. In women without endometriosis, EMX2 mRNA levels decline by $50 \%$ in periimplantation endometrium compared with levels in the proliferative phase. However, in the eutopic endometrium of women with endometriosis, such decline is not observed in the peri-implantation period. ${ }^{[57]}$ These findings suggest that EMX2 expression is also aberrant in eutopic endometrium of women with endometriosis and is mediated by altered Hoxa-10 expressions.

Integrins are a family of cell adhesion molecules that function in both cell-cell and cellsubstratum adhesion. They promote cell attachment to proteins within the extracellular matrix and potentiate cell migration and invasion. Many members of the integrin family are expressed by the endometrium throughout the menstrual cycle. Among these, the expression of $\alpha_{v} \beta_{3}$ integrin by endometrial epithelium is critical since its expression is coincident with the period of uterine receptivity. ${ }^{[58]}$ The apical surface of the luminal epithelium expresses the $\alpha_{v} \beta_{3}$ integrin and localizes to the pinopodes. ${ }^{[59]}$ This localization to the apical pole of the luminal epithelium suggests a role for this integrin in the initial embryo-endometrial interaction. ${ }^{[60]}$ The expression of integrin subunit $\beta_{3}$ seems to be significantly reduced in endometrium from women with unexplained infertility, endometriosis, hydrosalpinges, and luteal phase defect. In a prospective and double blind study, eighty-nine endometrial biopsies were taken before a diagnostic laparoscopy and the majority of women with reduced $\alpha_{v} \beta_{3}$ integrin expression during the time of implantation were shown to have stage I or II endometriosis. Based on these results, reduced $\alpha_{v} \beta_{3}$ integrin expression in endometriosis may be associated with decreased cycle fecundity due to defects in uterine receptivity. ${ }^{[61]}$ Interestingly, improvement of fertility and return of normal $\alpha_{v} \beta_{3}$ levels are observed after treating women with endometriosis with GnRH analogs and laser ablation of implants. ${ }^{[62]}$
Leukemia inhibitory factor and IL-11 belong to the IL-6-type cytokine family, which frequently exhibit pleiotropy and often have overlapping functions. ${ }^{[63,64]}$ Both IL-11 and LIF signal via a heterodimeric receptor complex comprising either the specific IL-11 receptor (R) $\alpha$-chain or the low affinity receptor LIF-R, associated with the common signaling component gp130 and signal transduction is through the JAK/STAT pathway ${ }^{[63,64]}$ Studies in mice have identified IL-11 and LIF to be obligatory for the earliest stages of implantation. Female mice with a null mutation of the IL- 11R $\alpha$ gene are infertile due to a defective decidualization response to the implanting blastocyst and female mice with no functional LIF gene are infertile due to an inability of normal embryos to implant. ${ }^{[65-67]}$ In mid-secretory phase human endometrium, IL-11, LIF, and LIF$\mathrm{R}$ are both expressed predominantly in glandular and luminal epithelium and are also thought to be important in decidualization and implantation in human. ${ }^{[68-70]}$ It is demonstrated that IL-11 and IL-11R $\alpha$ are not expressed in endometrium of infertile women with endometriosis. ${ }^{[7]}$ Moreover, LIF expression in eutopic glandular epithelium is significantly lower in infertile women with endometriosis compared to fertile controls. ${ }^{[71]}$ These results suggest that reduced endometrial IL-11 and LIF expression may contribute to infertility in some women with endometriosis.

The development of assisted reproductive techniques provides a tool to study the components involved in implantation separately. Most data from in-vitro fertilization (IVF) cycles fail to show any difference between implantation rates in women with and without endometriosis. ${ }^{[72-76]}$ Only a few studies show statistically significant lower implantation and pregnancy rates with IVF in women with early as well as late stages of the disease. ${ }^{[12,13,77]}$ Oocyte donation programs allow us to better understand whether the endometrium or the oocyte or both are affected in endometriosis. In women with endometriosis, donor oocytes obtained from women without the disease implant as efficiently as in other recipients. Furthermore, reduced pregnancy and implantation rates are observed when 
oocytes come from donors with endometriosis. ${ }^{[13]}$ In another study, oocytes from healthy donors are split in the same cycle and "sibling" oocytes are given to different recipients with or without endometriosis. Recipients in that study have stage III-IV endometriosis, and they have the same implantation rates as controls. ${ }^{[781}$ These data are confirmed by another study in which women received fresh donor oocytes because of a low response in their previous IVF cycles. In the donor oocyte cycle, women with endometriosis have a similar pregnancy rate as other women without endometriosis but with premature ovarian failure or menopause. ${ }^{[7]]}$ These data suggest that endometriosis may affect the oocyte/embryo and not the endometrium, because the implantation rates are similar to those of women without endometriosis when oocytes are donated by healthy women. Although it may not be appropriate to compare natural cycles with IVF cycles, where hormone levels are elevated, we would speculate that subtle impairments in the endometrial receptivity that may be relevant in natural cycles may be overcome by supraphysiologic hormone levels.

\section{CONCLUSION}

Endometriosis is associated with a decrease in cycle fecundity, and the prevalence of endometriosis is increased in infertile women. The study of endometrium in women with endometriosis continues to yield interesting differences when compared to women without this disease. The greatest obstacle to understanding how endometriosis alters fertility is the heterogeneity of this disorder. In addition, in lieu of biomarkers that predict the presence of endometriosis in the general population, our control groups may also contain confounding and occult disease that limits our ability to study this disorder. Biomarkers of uterine receptivity may provide a key to both of these questions. If we can develop markers that predict all endometriosis, we will be able to ascertain the true prevalence of this disease. If we find endometrial biomarkers that predict potential for pregnancy, then studies to examine the effect of endometriosis on fertility will likely have greater concordance. We also predict that studies to examine the effect of medical treatment will demonstrate efficacy in select populations of women. Further research into the use of such biomarkers holds the key to our future successes in these areas.

Clinical studies suggest decreased oocyte and embryo quality with lower capacity to implant in women with endometriosis. This can be explained by altered intrafollicular milieu influencing oocyte growth and development, and embryotoxicity of intraperitoneal environment.

In summary, women with endometriosis display lower implantation capacity and diminished pregnancy rates. However, the pathophysiology by which endometriosis affects implantation is an unresolved medical question.

\section{REFERENCES}

1. Berkkanoglu M, Arici A. Immunology and endometriosis. Am J Reprod Immunol 2003;50:48-59.

2. Jamieson DJ, Steege JF. The prevalence of dysmenorrhea, dyspareunia, pelvic pain, and irritable bowel syndrome in primary care practices. Obstet Gynecol 1996;87:55-8.

3. Houston DE. Evidence for the risk of pelvic endometriosis by age, race and socioeconomic status. Epidemiol Rev 1984;6:167-91.

4. Strathy JH, Molgaard CA, Coulam CB, Melton LJ. Endometriosis and infertility: a laparoscopic study of endometriosis among fertile and infertile women. Fertil Steril 1982;38:667-72.

5. Tummon IS, Maclin VM, Radwanska E, Binor Z, Dmowski WP. Occult ovulatory dysfunction in women with minimal endometriosis or unexplained infertility. Fertil Steril 1988;50:716-20.

6. Dmowski WP, Radwanska E, Binor Z, Rana N. Mild endometriosis and ovulatory dysfunction: effect of danazol treatment on success of ovulation induction. Fertil Steril 1986;46:784-9.

7. Soldati G, Piffaretti-Yanez A, Campana A, Marchini M, Luerti M, Balerna M. Effect of peritoneal fluid on sperm motility and velocity distribution using objective measurements. Fertil Steril 1989;52:113-9.

8. Mahadevan MM, Trounson AO, Leeton JF. The relationship of tubal blockage, infertility of unknown cause, suspected male infertility, and endometriosis to success of in vitro fertilization and embryo transfer. Fertil Steril 1983;40:755-62.

9. Wardle PG, Mitchell JD, McLaughlin EA, Ray BD, McDermott A, Hull MG. Endometriosis and ovulatory disorder: reduced fertilisation in vitro compared with tubal and unexplained infertility. Lancet 
$1985 ; 2: 236-9$.

10. Damewood MD, Hesla JS, Schlaff WD, Hubbard M, Gearhart JD, Rock JA. Effect of serum from patients with minimal to mild endometriosis on mouse embryo development in vitro. Fertil Steril 1990; 54:917-20.

11. Simón C, Gómez E, Mir A, De los Santos MJ, Pellicer A. Glucocorticoid treatment decreases sera embryotoxicity in endometriosis patients. Fertil Steril 1992; 58:284-9.

12. Matson PL, Yovich JL. The treatment of infertility associated with endometriosis by in vitro fertilization. Fertil Steril 1986;46:432-4.

13. Simón C, Gutiérrez A, Vidal A, de los Santos MJ, Tarín JJ, Remohí J, et al. Outcome of patients with endometriosis in assisted reproduction: results from in-vitro fertilization and oocyte donation. Hum Reprod 1994;9:725-9.

14. Seli E, Berkkanoglu M, Arici A. Pathogenesis of endometriosis. Obstet Gynecol Clin North [Am] 2003;30:41-61.

15. Hill JA, Faris HM, Schiff I, Anderson DJ. Characterization of leukocyte subpopulations in the peritoneal fluid of women with endometriosis. Fertil Steril 1988;50:216-22.

16. Fakih H, Baggett B, Holtz G, Tsang KY, Lee JC, Williamson HO. Interleukin-1: a possible role in the infertility associated with endometriosis. Fertil Steril 1987;47:213-7.

17. Hill JA, Anderson DJ. Lymphocyte activity in the presence of peritoneal fluid from fertile women and infertile women with and without endometriosis. Am J Obstet Gynecol 1989;161:861-4.

18. Mori H, Sawairi M, Nakagawa M, Itoh N, Wada K, Tamaya T. Peritoneal fluid interleukin-1 beta and tumor necrosis factor in patients with benign gynecologic disease. Am J Reprod Immunol 1991;26:62-7.

19. Arici A, Tazuke SI, Attar E, Kliman HJ, Olive DL. Interleukin-8 concentration in peritoneal fluid of patients with endometriosis and modulation of interleukin-8 expression in human mesothelial cells. Mol Hum Reprod 1996;2:40-5.

20. Ryan IP, Tseng JF, Schriock ED, Khorram O, Landers DV, Taylor RN. Interleukin-8 concentrations are elevated in peritoneal fluid of women with endometriosis. Fertil Steril 1995;63:929-32.

21. Arici A, Oral E, Attar E, Tazuke SI, Olive DL. Monocyte chemotactic protein-1 concentration in peritoneal fluid of women with endometriosis and its modulation of expression in mesothelial cells. Fertil Steril 1997;67:1065-72.

22. Taketani Y, Kuo TM, Mizuno M. Comparison of cytokine levels and embryo toxicity in peritoneal fluid in infertile women with untreated or treated endometriosis. Am J Obstet Gynecol 1992;167:265-70.

23. Khorram O, Taylor RN, Ryan IP, Schall TJ, Landers DV. Peritoneal fluid concentrations of the cytokine RANTES correlate with the severity of endometriosis. Am J Obstet Gynecol 1993;169:1545-9.

24. McLaren J, Prentice A, Charnock-Jones DS, Millican SA, Müller KH, Sharkey AM, et al. Vascular endothelial growth factor is produced by peritoneal fluid macrophages in endometriosis and is regulated by ovarian steroids. J Clin Invest 1996;98:482-9.

25. Navarro J, Garrido N, Remohi J, Pellicer A. How does endometriosis affect infertility? Obstet Gynecol Clin North [Am] 2003;30:181-92.

26. Pellicer A, Albert C, Mercader A, Bonilla-Musoles F, Remohi J, Simon C. The follicular and endocrine environment in women with endometriosis: local and systemic cytokine production. Fertil Steril 1998; 70:425-31.

27. Carlberg M, Nejaty J, Fröysa B, Guan Y, Söder O, Bergqvist A. Elevated expression of tumour necrosis factor alpha in cultured granulosa cells from women with endometriosis. Hum Reprod 2000;15:1250-5.

28. Abaé M, Glassberg M, Majercik MH, Yoshida $H$, Vestal R, Puett D. Immunoreactive endothelin-1 concentrations in follicular fluid of women with and without endometriosis undergoing in vitro fertilization-embryo transfer. Fertil Steril 1994;61:1083-7.

29. Oral E, Seli E, Bahtiyar MO, Jones EE, Arici A. Growth-regulated alpha expression in human preovulatory follicles and ovarian cells. Am J Reprod Immunol 1997;38:19-25.

30. Lee KS, Joo BS, Na YJ, Yoon MS, Choi OH, Kim WW. Relationships between concentrations of tumor necrosis factor-alpha and nitric oxide in follicular fluid and oocyte quality. J Assist Reprod Genet 2000; 17:222-8.

31. Van Blerkom J, Antczak M, Schrader R. The developmental potential of the human oocyte is related to the dissolved oxygen content of follicular fluid: association with vascular endothelial growth factor levels and perifollicular blood flow characteristics. Hum Reprod 1997;12:1047-55.

32. Kasson BG, Gorospe WC. Effects of interleukins 1, 2 and 3 on follicle-stimulating hormone-induced differentiation of rat granulosa cells. Mol Cell Endocrinol 1989;62:103-11.

33. Roby KF, Terranova PF. Effects of tumor necrosis factor-alpha in vitro on steroidogenesis of healthy and atretic follicles of the rat: theca as a target. Endocrinology 1990;126:2711-8.

34. Barnhart K, Dunsmoor-Su R, Coutifaris C. Effect of endometriosis on in vitro fertilization. Fertil Steril 2002;77:1148-55.

35. Mahutte NG, Arici A. New advances in the understanding of endometriosis related infertility. J Reprod Immunol 2002;55:73-83.

36. Nakahara K, Saito $H$, Saito $T$, Ito $M$, Ohta $N$, Takahashi T, Hiroi M. The incidence of apoptotic bodies in membrana granulosa can predict prognosis of ova from patients participating in in vitro fertilization programs. Fertil Steril 1997;68:312-7.

37. Saito H, Seino T, Kaneko T, Nakahara K, Toya M, Kurachi H. Endometriosis and oocyte quality. Gynecol Obstet Invest 2002;53:46-51.

38. Abu-Musa A, Takahashi K, Kitao M. The effect of serum obtained before and after treatment for endometriosis on in vitro development of two-cell mouse embryos. Fertil Steril 1992;57:1098-102.

39. Morcos RN, Gibbons WE, Findley WE. Effect of peri- 
toneal fluid on in vitro cleavage of 2-cell mouse embryos: possible role in infertility associated with endometriosis. Fertil Steril 1985;44:678-83.

40. Prough SG, Aksel S, Gilmore SM, Yeoman RR. Peritoneal fluid fractions from patients with endometriosis do not promote two-cell mouse embryo growth. Fertil Steril 1990;54:927-30.

41. Martinez-Roman S, Balasch J, Creus M, Fabregues F, Carmona F, Vilella R, et al. Immunological factors in endometriosis-associated reproductive failure: studies in fertile and infertile women with and without endometriosis. Hum Reprod 1997;12:1794-9.

42. Brizek CL, Schlaff S, Pellegrini VA, Frank JB, Worrilow KC. Increased incidence of aberrant morphological phenotypes in human embryogenesis-an association with endometriosis. J Assist Reprod Genet 1995;12:106-12.

43. Pellicer A, Oliveira N, Ruiz A, Remohí J, Simón C. Exploring the mechanism(s) of endometriosis-related infertility: an analysis of embryo development and implantation in assisted reproduction. Hum Reprod 1995;10 Suppl 2:91-7.

44. Tanbo T, Omland A, Dale PO, Abyholm T. In vitro fertilization/embryo transfer in unexplained infertility and minimal peritoneal endometriosis. Acta Obstet Gynecol Scand 1995;74:539-43.

45. Giudice LC. Potential biochemical markers of uterine receptivity. Hum Reprod 1999;14 Suppl 2:3-16.

46. Navot D, Scott RT, Droesch K, Veeck LL, Liu HC, Rosenwaks Z. The window of embryo transfer and the efficiency of human conception in vitro. Fertil Steril 1991;55:114-8.

47. Cavagna M, Mantese JC. Biomarkers of endometrial receptivity-a review. Placenta 2003;24 Suppl B:S39-47.

48. Lessey BA. The role of the endometrium during embryo implantation. Hum Reprod 2000;15:39-50.

49. Edwards RG. Clinical approaches to increasing uterine receptivity during human implantation. Hum Reprod 1995;10:60-6.

50. Taylor HS, Vanden Heuvel GB, Igarashi P. A conserved Hox axis in the mouse and human female reproductive system: late establishment and persistent adult expression of the Hoxa cluster genes. Biol Reprod 1997;57:1338-45.

51. Taylor HS, Arici A, Olive D, Igarashi P. HOXA10 is expressed in response to sex steroids at the time of implantation in the human endometrium. J Clin Invest 1998;101:1379-84.

52. Salehnia M. Different pattern of pinopodes expression in stimulated mouse endometrium. Exp Anim 2005;54:349-52.

53. Nikas G. Cell-surface morphological events relevant to human implantation. Hum Reprod 1999;14:37-44.

54. Garcia-Velasco JA, Simon C, Ardiles G. Assessment of endometrial response to HRT using the detection of pinopodes in women with endometriosis undergoing oocyte donation. In: 4th Meeting of the American Society of Reproductive Medicine; October 4-9, 1998; San Francisco, California, USA; 1998. p. 242.

55. Taylor HS. The role of HOX genes in human implantation. Hum Reprod Update 2000;6:75-9.
56. Taylor HS, Bagot C, Kardana A, Olive D, Arici A. HOX gene expression is altered in the endometrium of women with endometriosis. Hum Reprod 1999; 14:1328-31.

57. Daftary GS, Taylor HS. EMX2 gene expression in the female reproductive tract and aberrant expression in the endometrium of patients with endometriosis. J Clin Endocrinol Metab 2004;89:2390-6.

58. Lessey BA, Damjanovich L, Coutifaris C, Castelbaum A, Albelda SM, Buck CA. Integrin adhesion molecules in the human endometrium. Correlation with the normal and abnormal menstrual cycle. J Clin Invest 1992;90:188-95.

59. Adams EC, Hertig AT, Rock J. A description of 34 human ova within the first 17 days of development. Am J Anat 1956:98:435-93.

60. Navot D, Bergh PA, Williams M, Garrisi GJ, Guzman I, Sandler B, et al. An insight into early reproductive processes through the in vivo model of ovum donation. J Clin Endocrinol Metab 1991;72:408-14.

61. Lessey BA, Castelbaum AJ, Sawin SW, Buck CA, Schinnar R, Bilker W, et al. Aberrant integrin expression in the endometrium of women with endometriosis. J Clin Endocrinol Metab 1994;79:643-9.

62. Lessey BA, Young SL. Integrins and other cell adhesion molecules in endometrium and endometriosis. Semin Reprod Endocrinol 1997;15:291-9.

63. Cakmak H, Schatz F, Huang ST, Buchwalder L, Rahman M, Arici A, et al. Progestin suppresses thrombin- and interleukin-1beta-induced interleukin-11 production in term decidual cells: implications for preterm delivery. J Clin Endocrinol Metab 2005;90:5279-86.

64. Seli E, Kayisli UA, Cakmak H, Bukulmez O, Bildirici I, Guzeloglu-Kayisli O, et al. Removal of hydrosalpinges increases endometrial leukaemia inhibitory factor (LIF) expression at the time of the implantation window. Hum Reprod 2005;20:3012-7.

65. Bilinski P, Roopenian D, Gossler A. Maternal IL11Ralpha function is required for normal decidua and fetoplacental development in mice. Genes Dev 1998;12:2234-43.

66. Robb L, Li R, Hartley L, Nandurkar HH, Koentgen F, Begley CG. Infertility in female mice lacking the receptor for interleukin 11 is due to a defective uterine response to implantation. Nat Med 1998;4:303-8.

67. Stewart CL, Kaspar P, Brunet LJ, Bhatt H, Gadi I, Köntgen F, et al. Blastocyst implantation depends on maternal expression of leukaemia inhibitory factor. Nature 1992;359:76-9.

68. Aghajanova L, Stavreus-Evers A, Nikas Y, Hovatta $\mathrm{O}$, Landgren BM. Coexpression of pinopodes and leukemia inhibitory factor, as well as its receptor, in human endometrium. Fertil Steril 2003;79:808-14.

69. Cork BA, Li TC, Warren MA, Laird SM. Interleukin11 (IL-11) in human endometrium: expression throughout the menstrual cycle and the effects of cytokines on endometrial IL-11 production in vitro. J Reprod Immunol 2001;50:3-17.

70. Cullinan EB, Abbondanzo SJ, Anderson PS, Pollard JW, Lessey BA, Stewart CL. Leukemia inhibitory factor (LIF) and LIF receptor expression in human en- 
dometrium suggests a potential autocrine/paracrine function in regulating embryo implantation. Proc Natl Acad Sci USA 1996;93:3115-20.

71. Dimitriadis E, Stoikos C, Stafford-Bell M, Clark I, Paiva P, Kovacs G, et al. Interleukin-11, IL-11 receptoralpha and leukemia inhibitory factor are dysregulated in endometrium of infertile women with endometriosis during the implantation window. J Reprod Immunol 2006;69:53-64.

72. Inoue M, Kobayashi Y, Honda I, Awaji H, Fujii A. The impact of endometriosis on the reproductive outcome of infertile patients. Am J Obstet Gynecol 1992;167:278-82.

73. Dmowski WP, Rana N, Michalowska J, Friberg J, Papierniak C, el-Roeiy A. The effect of endometriosis, its stage and activity, and of autoantibodies on in vitro fertilization and embryo transfer success rates. Fertil Steril 1995;63:555-62.

74. Olivennes F, Feldberg D, Liu HC, Cohen J, Moy F, Rosenwaks Z. Endometriosis: a stage by stage analysis-the role of in vitro fertilization. Fertil Steril 1995; 64:392-8.
75. Pal L, Shifren JL, Isaacson KB, Chang Y, Leykin L, Toth TL. Impact of varying stages of endometriosis on the outcome of in vitro fertilization-embryo transfer. J Assist Reprod Genet 1998;15:27-31.

76. Bukulmez O, Yarali H, Gurgan T. The presence and extent of endometriosis do not effect clinical pregnancy and implantation rates in patients undergoing intracytoplasmic sperm injection. Eur J Obstet Gynecol Reprod Biol 2001;96:102-7.

77. Azem F, Lessing JB, Geva E, Shahar A, Lerner-Geva L, Yovel I, et al. Patients with stages III and IV endometriosis have a poorer outcome of in vitro fertilization-embryo transfer than patients with tubal infertility. Fertil Steril 1999;72:1107-9.

78. Diaz I, Navarro J, Blasco L, Simon C, Pellicer A, Remohi J. Impact of stage III-IV endometriosis on recipients of sibling oocytes: matched case-control study. Fertil Steril 2000;74:31-4.

79. Remohi J, Ardiles G, Garcia-Velasco JA, Gaitan P, Simon C, Pellicer A. Endometrial thickness and serum oestradiol concentrations as predictors of outcome in oocyte donation. Hum Reprod 1997;12:2271-6. 